\title{
Emergency Slaughter of Cattle in the Czech Republic: the Most Frequent Causes and their Occurrence in the Period of 1997-2002
}

\author{
V. VEČEREK ${ }^{1}$, B. BARTOŠEK ${ }^{1}$, A. KOZÁK ${ }^{2}$, P. CHLOUPEK ${ }^{1}$, V. PIŠTĚKOVÁ ${ }^{1}$ \\ ${ }^{1}$ University of Veterinary and Pharmaceutical Sciences, Brno, Czech Republic \\ ${ }^{2}$ Veterinary Administration of the City of Prague, Prague, Czech Republic \\ Received May 5, 2003 \\ Accepted September 22, 2003
}

\begin{abstract}
Večerek V., B. Bartošek, A. Kozák, P. Chloupek, V. Pištěková: Emergency Slaughter of Cattle in the Czech Republic: the Most Frequent Causes and their Occurrence in the Period of 1997-2002. Acta Vet Brno 2003, 72: 445-452.

The objective of the present study was to investigate the most frequent causes for emergency slaughters of the cattle and to compare the causes of emergency slaughters in two consecutive periods. From 1997 to 2002, the cases of emergency slaughter of calves, heifers, cows and slaughter bulls were monitored at abattoirs in the whole of the Czech Republic. The reasons for the emergency slaughter were divided into the following categories: infections, respiratory apparatus diseases, digestive apparatus diseases, locomotor apparatus diseases, post-parturition complications, diseases of other aetiologies. The period of 2000 to 2002 (period II) was compared with the period of 1997 to 1999 (period I) on the basis of an index of relative frequencies of findings during period II and period I. In the category of calves, the most frequent finding were respiratory apparatus diseases $(47.43 \%$ ), with slight increase during period II (index 1.07) that was highly significant $(P \leq 0.01)$. The most frequent finding among heifers, cows and bulls were diseases of the locomotor apparatus (heifers $43.07 \%$; cows $35.30 \%$; bulls $58.27 \%$ ). Slight increase during period II (heifers index 1.07; cows index 1.07; bulls index 1.06) was highly significant (heifers $P \leq$ 0.01 ; cows $P \leq 0.01$; bulls $P \leq 0.01$ ). Emergency slaughters in different categories were differently reflected in the frequency of condemnation decisions (calves $61.24 \%$, heifers $30.14 \%$, cows $45.16 \%$, bulls $17.92 \%$ ). An increase of the values during period II was recorded for calves (index 1.23 ) and cows (index 1.08). The increase was highly significant (calves $P \leq 0.01$; cows $P \leq 0.01$ ); no significance was found for the difference between the values for periods I and II for heifers and bulls, significant for heifers $P=0.89$ and for bulls $P=0.93$. Changes in cattle herds to improve their health and reduce the number of emergency slaughters should include measures to fight respiratory apparatus diseases in calves and locomotor apparatus diseases in the other categories of cattle.
\end{abstract}

Carcasses, fit, human consumption, cows, heifers, bulls, calves, respiratory diseases, locomotor diseases

The number of emergency slaughters of the cattle and their causes are an indicator of the health status of the cattle on farms. The reasons for emergency slaughter may point to the existence of stressful situations for the cattle on farms, and they may be indicative of the type of changes that need to be made in the herd to improve its health status. Veterinary inspections of the meat and the viscera at abattoirs serve to verify the reasons for the emergency slaughter. The importance of findings obtained at veterinary inspections at abattoirs and of their evaluation was emphasized by Kofer et al. (2001). W ys s (1996) explains that veterinary inspections are based on examinations by inspection, palpation and dissection of carcasses and their organs, and on laboratory results obtained from tissue samples, scrapings and impressions. Based on such veterinary post mortem inspections, decisions whether carcasses of emergency slaughter animals are to be passed for human consumption, conditionally passed for human consumption or condemned are then taken.

Address for correspondence:

Doc. MVDr. Vladimír Večerek, CSc.

University of Veterinary and Pharmaceutical Sciences

242 Brno
Phone: +420541562614

Fax: +420549243020

http://www.vfu.cz/acta-vet/actavet.htm 
The numbers of carcasses passed as fit for human consumption, conditionally passed for human consumption and condemned at abattoirs were monitored by Kozák et al. (2002). Comparing the 1989 to 1994 period and the 1995 to 2000 period in the Czech Republic, they found an increase in the number of cow carcasses unfit for human consumption from $6.43 \%$ to $8.64 \%$, and also a slight increase in condemned calf carcasses (from $19.26 \%$ to $20.28 \%$ ). They also found a slight decrease in the number of heifers declared unfit for human consumption from $3.54 \%$ in the 1989 to 1994 period to $2.30 \%$ in the 1995 to 2000 period, and reported a similar trend for bulls (a decrease from $1.32 \%$ to $0.58 \%$ ).

The frequency of pathological findings in carcasses at abattoirs was also studied by a number of other authors. Those authors, however, focused on specific findings. The most frequent findings of Julini (1993), who examined cattle at abattoirs in Alessandria (Italy, Piedmont region) between 1980 and 1985, were chronic bronchopneumonia, TBC, distomatoses, liver abscesses, fibroplastic nephritis and cysticercosis in bullocks, TBC, distomatoses and pyelonephritis in cows, and chronic bronchopneumonias and hepatoses in calves. Examining cattle carcasses at abattoirs in the Turin and Cuneo areas (Italy, Piedmont region), Giaccone et al. (1994) reported distomatoses as the principal reason for the condemnation of the liver. Biss et al. (1994) report results of their analysis of findings made during inspections of condemned calf carcasses. In their set of 370 calves, they found that the most frequent findings were the disease of the navel (138 cases), enzootic pneumonia (75 cases), arthritis of the joints ( 32 cases), focal interstitial nephritis (35 cases), injury (23 cases), and a few cases of icterus, generalized peritonitis and liver abscesses.

The objectives of the present study were to identify the most frequent causes for emergency slaughters of the cattle, to assess the relationship between emergency slaughters and decisions whether to pass cattle carcasses or condemn them as unfit for human consumption, and to compare the frequencies in two subsequent periods. The results are important for the development of measures that help improve the health status in herds and reduce the number of emergency slaughters.

\section{Materials and Methods}

In the period between 1997 and 2002, emergency slaughters of cattle at Czech abattoirs were monitored. For selected categories of the cattle, i.e. calves, heifers, cows and slaughter bulls, veterinary inspectors in the Czech Republic recorded numbers of emergency slaughters in cattle and results of veterinary inspection of emergency slaughter carcasses. The findings were categorized according to the following causes for emergency slaughters: infections, respiratory apparatus diseases, digestive apparatus diseases, locomotor apparatus diseases, postparturition complications, and diseases of other aetiologies. A record was also made of the veterinary surgeon's decision whether to pass those carcasses for human consumption, to conditionally pass them for human consumption or to condemn them as unfit for human consumption.

The results were put in a computer and sent for centralized processing to the information centre of the State Veterinary Administration, where the frequency of individual emergency slaughter causes together with decisions on the condemnation or passing of the carcasses were recorded over the entire period of monitoring $(1997$ - 2002) for each of the cattle categories. For each of the cattle categories, ratios of individual emergency slaughter causes and condemnation decisions to the total number of emergency slaughters were calculated. The monitoring period was divided into two parts - part I (1997 to 1999) and part II (2000 to 2002) were evaluated separately. To compare the two periods, an index was calculated as a ratio of the 2000 to 2002 figures to the 1997 to 1999 figures. An index higher than 1.00 means that the frequency of a specific cause for the emergency slaughter or of condemnation decisions for a specific cattle category in the 2000 to 2002 period grew compared with the 1997 to 1999 period, i.e. that there was a growing trend in the frequency of that specific cause for the emergency slaughter or of condemnation decisions for that specific cattle category. If the index equalled 1.00, there was no increase in the number of emergency slaughter cases or condemnation decisions for that particular cattle category. An index below 1.00 indicated a decrease in the frequency of the cause for the emergency slaughter or of condemnation decisions for the given cattle category in the 2000 to 2002 period compared with the 1997 to 1999 period, i.e. a downward trend in the frequency of that particular cause for the emergency slaughter or condemnation decisions for that particular cattle category. To calculate the statistical significance of the difference between monitored periods for 
individual causes for the emergency slaughter and for condemnation decisions for specific cattle categories, the results were statistically processed by the Unistat (Unistat Statistical Package - Unistat Ltd) module allowing frequency comparisons on the basis of contingency table and $\chi^{2}$ test.

\section{Results}

Absolute numbers of emergency slaughters in calves, heifers, cows and bulls during the monitored period are summarized in Fig. 1. The results indicated that the largest number of emergency slaughters occurred in cows, less in calves and bulls, and the smallest number was in heifers. The comparison between the periods of 1997 to 1999 vs. 2000 to 2002 showed that absolute numbers of emergency slaughters increased in cows and bulls, whereas in heifers the number of emergency slaughters decreased. However, the decrease was caused in particular by the fact that total number of animals slaughtered was significantly reduced. Fig. 2 shows the numbers of emergency slaughters adjusted to total numbers of slaughters. The results demonstrated that the proportion of emergency slaughters out of all slaughters was on the increase in all categories of cattle. Comparison of periods I and II clearly depicts the trend.

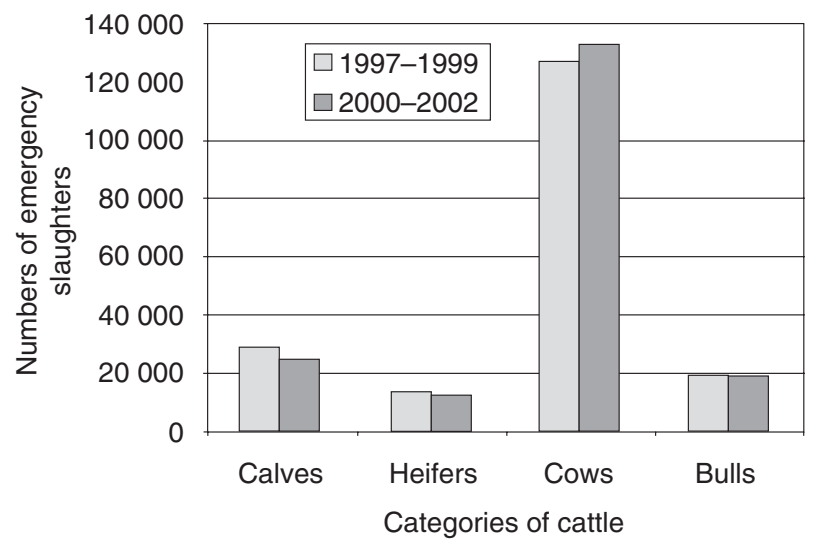

Fig. 1. Absolute numbers of emergency slaughters during the monitored period

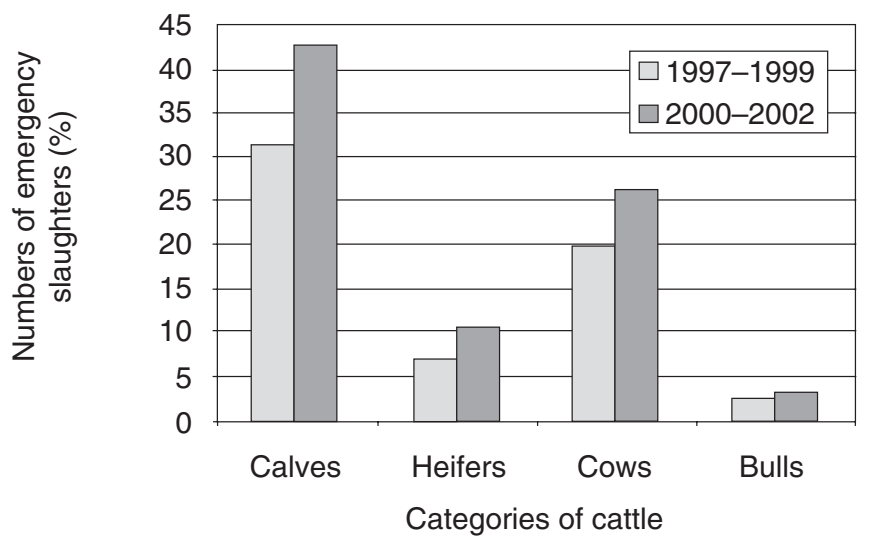

Fig. 2. Relative numbers of emergency slaughters during the monitored period 
Individual causes for emergency slaughters and condemnation decisions for cattle categories monitored in absolute and relative frequencies for the entire period from 1997 to 2002, and for periods from 1997 to 1999 and from 2000 to 2002, and the comparison of both periods expressed as an index of decreasing or increasing relative frequencies of individual causes for emergency slaughters and condemnation decisions are given in the tabular format.

It follows from the results in Table 1 that the most frequent cause of emergency slaughters for calves were respiratory apparatus diseases $(47.43 \%)$, with a moderately upward value for period II (index 1.07). The difference was highly significant $(P \leq 0.01)$. Tab. 1 also shows that $61.24 \%$ of calf carcasses from emergency slaughters were condemned, with an upward value for period II (index 1.23). This difference was also significant $(P \leq 0.01)$.

Table 1

Emergency slaughters of calves during the period of 1997 to 2002

\begin{tabular}{|c|c|c|c|c|c|c|c|c|}
\hline \multirow{3}{*}{$\begin{array}{l}\text { Causes for emergency } \\
\text { slaughter }\end{array}$} & \multicolumn{2}{|c|}{1997 to 2002} & \multicolumn{2}{|c|}{1997 to 1999} & \multicolumn{2}{|c|}{2000 to 2002} & \multirow{2}{*}{$\begin{array}{l}\text { Ratio } \\
\mathrm{B} / \mathrm{A}\end{array}$} & \multirow{2}{*}{$\begin{array}{c}\text { Statistical } \\
\text { significance }\end{array}$} \\
\hline & & & & A & & $\mathrm{B}$ & & \\
\hline & No. & $\%$ & No. & $\%$ & No. & $\%$ & index & $P$ \\
\hline Infections & 32 & 0.06 & 23 & 0.08 & 9 & 0.04 & 0.45 & $0.04 *$ \\
\hline Respiratory apparatus diseases & 25239 & 47.43 & 13160 & 46.00 & 12079 & 49.09 & 1.07 & $0.00 * *$ \\
\hline Digestive apparatus diseases & 4902 & 9.21 & 2807 & 9.81 & 2095 & 8.51 & 0.87 & $0.00 * *$ \\
\hline Locomotor apparatus diseases & 11266 & 21.17 & 5926 & 20.71 & 5340 & 21.70 & 1.05 & $0.00^{* *}$ \\
\hline Post-parturition complications & 40 & 0.08 & 31 & 0.11 & 9 & 0.04 & 0.34 & $0.00 * *$ \\
\hline Diseases of other aetiologies & 11737 & 22.06 & 6663 & 23.29 & 5074 & 20.62 & 0.89 & $0.00 * *$ \\
\hline Total & 53216 & 100.00 & 28610 & 100.00 & 24606 & 100.00 & 1.00 & \\
\hline Condemned & 32592 & 61.24 & 15861 & 55.44 & 16731 & 68.00 & 1.23 & $0.00 * *$ \\
\hline $\begin{array}{l}\text { Conditionally passed as fit for } \\
\text { consumption }\end{array}$ & 18443 & 34.66 & 11662 & 40.76 & 6781 & 27.56 & 0.68 & $0.00 * *$ \\
\hline Passed as fit for consumption & 2177 & 4.09 & 1087 & 3.80 & 1090 & 4.43 & 1.17 & $0.00 * *$ \\
\hline
\end{tabular}

Table 2 gives the results for heifers. The most frequent cause for emergency slaughter in this case was diseases of the locomotor apparatus (43.07\%), with a moderately upward value for period II (index 1.07). The difference was highly significant $(P \leq 0.01)$. The condemnation decision figures show that $30.14 \%$ of heifer carcasses from emergency slaughters were condemned as unfit for human consumption. No significant difference was found between the two parts of the period.

Table 2

Emergency slaughters of heifers during the period of 1997 to 2002

\begin{tabular}{|c|c|c|c|c|c|c|c|c|}
\hline \multirow{3}{*}{$\begin{array}{l}\text { Causes for emergency } \\
\text { slaughter }\end{array}$} & \multicolumn{2}{|c|}{1997 to 2002} & \multicolumn{2}{|c|}{1997 to 1999} & \multicolumn{2}{|c|}{2000 to 2002} & \multirow{2}{*}{$\begin{array}{l}\text { Ratio } \\
\text { B/A }\end{array}$} & \multirow{2}{*}{$\begin{array}{l}\text { Statistical } \\
\text { significance }\end{array}$} \\
\hline & & & & $\mathrm{A}$ & & $\mathrm{B}$ & & \\
\hline & No. & $\%$ & No. & $\%$ & No. & $\%$ & index & $P$ \\
\hline Infections & 106 & 0.40 & 27 & 0.20 & 79 & 0.63 & 3.17 & $0.00 * *$ \\
\hline Respiratory apparatus diseases & 4294 & 16.33 & 2200 & 16.10 & 2094 & 16.58 & 1.03 & 0.30 \\
\hline Digestive apparatus diseases & 2021 & 7.69 & 1110 & 8.12 & 911 & 7.21 & 0.89 & $0.00 * *$ \\
\hline Locomotor apparatus diseases & 11325 & 43.07 & 5690 & 41.64 & 5635 & 44.61 & 1.07 & $0.00 * *$ \\
\hline Post-parturition complications & 1211 & 4.61 & 591 & 4.33 & 620 & 4.91 & 1.13 & $0.02 *$ \\
\hline Diseases of other aetiologies & 7338 & 27.91 & 4046 & 29.61 & 3292 & 26.06 & 0.88 & $0.00 * *$ \\
\hline Total & 26295 & 100.00 & 13664 & 100.00 & 12631 & 100.00 & 1.00 & \\
\hline Condemned & 7924 & 30.14 & 4123 & 30.17 & 3801 & 30.09 & 1.00 & 0.89 \\
\hline $\begin{array}{l}\text { Conditionally passed as fit for } \\
\text { consumption }\end{array}$ & 14981 & 56.97 & 7732 & 56.59 & 7249 & 57.39 & 1.01 & 0.19 \\
\hline Passed as fit for consumption & 3390 & 12.89 & 1809 & 13.24 & 1581 & 12.52 & 0.95 & 0.08 \\
\hline
\end{tabular}


Table 3 gives the results for the category of cows. The most frequent cause for emergency slaughter in this category were the diseases of the locomotor apparatus $(35.30 \%)$, followed by diseases of other aetiologies (29.94\%), with a moderately upward value for period II for both the diseases of the locomotor apparatus and the diseases of other aetiologies (indices 1.07 and 1.08 , respectively); both differences were highly significant $(P \leq 0.01)$. The condemnation decision figures show that $45.16 \%$ of cow carcasses from emergency slaughters were condemned, with a moderately upward value for period II (index 1.08); the difference was highly significant $(P \leq 0.01)$.

Table 3

Emergency slaughters of cows during the period of 1997 to 2002

\begin{tabular}{|c|c|c|c|c|c|c|c|c|}
\hline \multirow{3}{*}{$\begin{array}{c}\text { Causes for emergency } \\
\text { slaughter }\end{array}$} & \multicolumn{2}{|c|}{1997 to 2002} & \multicolumn{2}{|c|}{1997 to 1999} & \multicolumn{2}{|c|}{2000 to 2002} & \multirow{2}{*}{$\begin{array}{c}\text { Ratio } \\
\text { B/A }\end{array}$} & \multirow{2}{*}{$\begin{array}{c}\text { Statistical } \\
\text { significance }\end{array}$} \\
\hline & & & & $\mathrm{A}$ & & $\mathrm{B}$ & & \\
\hline & No. & $\%$ & No. & $\%$ & No. & $\%$ & index & $P$ \\
\hline Infections & 375 & 0.14 & 172 & 0.14 & 203 & 0.15 & 1.13 & 0.04 \\
\hline Respiratory apparatus diseases & 2738 & 1.05 & 1292 & 1.01 & 1446 & 1.09 & 1.07 & 0.07 \\
\hline Digestive apparatus diseases & 43105 & 16.56 & 22136 & 17.38 & 20969 & 15.77 & 0.91 & $0.00 * *$ \\
\hline Locomotor apparatus diseases & 91903 & 35.30 & 43318 & 34.01 & 48585 & 36.54 & 1.07 & $0.00^{* *}$ \\
\hline Post-parturition complications & 44284 & 17.01 & 23789 & 18.68 & 20495 & 15.41 & 0.83 & $0.00 * *$ \\
\hline Diseases of other aetiologies & 77943 & 29.94 & 36673 & 28.79 & 41270 & 31.04 & 1.08 & $0.00 * *$ \\
\hline Total & 260348 & 100.00 & 127380 & 100.00 & 132968 & 100.00 & 1.00 & \\
\hline Condemned & 117570 & 45.16 & 55186 & 43.32 & 62384 & 46.92 & 1.08 & $0.00 * *$ \\
\hline $\begin{array}{l}\text { Conditionally passed as fit for } \\
\text { consumption }\end{array}$ & 127976 & 49.16 & 64651 & 50.75 & 63325 & 47.62 & 0.94 & $0.00 * *$ \\
\hline Passed as fit for consumption & 14802 & 5.69 & 7543 & 5.92 & 7259 & 5.46 & 0.92 & $0.00 * *$ \\
\hline
\end{tabular}

It follows from the results for slaughter bulls in Table 4 that the most frequent cause for emergency slaughters in this category are diseases of the locomotor apparatus $(58.27 \%)$, with a moderately upward value for period II (index 1.06); this difference was highly significant $(P \leq 0.01)$. The condemnation decision figures show that $17.92 \%$ of slaughter bull carcasses from emergency slaughters were condemned. No significant difference was found between the two parts of the period.

Table 4

Emergency slaughters of slaughter bulls during the period of 1997 to 2002

\begin{tabular}{|c|c|c|c|c|c|c|c|c|}
\hline \multirow{3}{*}{$\begin{array}{l}\text { Causes for emergency } \\
\text { slaughter }\end{array}$} & \multicolumn{2}{|c|}{1997 to 2002} & \multicolumn{2}{|c|}{1997 to 1999} & \multicolumn{2}{|c|}{2000 to 2002} & \multirow{2}{*}{$\begin{array}{c}\text { Ratio } \\
\mathrm{B} / \mathrm{A}\end{array}$} & \multirow[t]{2}{*}{$\begin{array}{l}\text { Statistical } \\
\text { significance }\end{array}$} \\
\hline & & & & $\mathrm{A}$ & & $\mathrm{B}$ & & \\
\hline & No. & $\%$ & No. & $\%$ & No. & $\%$ & index & $P$ \\
\hline Infections & 30 & 0.08 & 11 & 0.06 & 19 & 0.10 & 1.69 & 0.16 \\
\hline Respiratory apparatus diseases & 6585 & 16.71 & 3281 & 16.86 & 3304 & 16.57 & 0.98 & 0.43 \\
\hline Digestive apparatus diseases & 1913 & 4.86 & 1079 & 5.55 & 834 & 4.18 & 0.75 & $0.00 * *$ \\
\hline Locomotor apparatus diseases & 22957 & 58.27 & 11011 & 56.59 & 11946 & 59.90 & 1.06 & $0.00^{* *}$ \\
\hline Post-parturition complications & 44 & 0.11 & 25 & 0.13 & 19 & 0.10 & 0.74 & 0.32 \\
\hline Diseases of other aetiologies & 7872 & 19.98 & 4050 & 20.82 & 3822 & 19.16 & 0.92 & $0.00 * *$ \\
\hline Total & 39401 & 100.00 & 19457 & 100.00 & 19944 & 100.00 & 1.00 & \\
\hline Condemned & 7062 & 17.92 & 3484 & 17.91 & 3578 & 17.94 & 1.00 & 0.93 \\
\hline $\begin{array}{l}\text { Conditionally passed as fit for } \\
\text { consumption }\end{array}$ & 23762 & 60.31 & 11180 & 57.46 & 12582 & 63.09 & 1.10 & $0.00 * *$ \\
\hline Passed as fit for consumption & 8575 & 21.76 & 4793 & 24.63 & 3782 & 18.96 & 0.77 & $0.00 * *$ \\
\hline
\end{tabular}

Legend to Tables: * $*$ the difference in the number of findings between Period I and Period II is significant $P \leq 0.05$ ** $=$ the difference in the number of findings between Period I and Period II is highly significant $P \leq 0.01$ 


\section{Discussion}

The identification of the causes for emergency slaughter in different categories of the cattle helps reveal the kind of stressful situations experienced by animals from those categories that negatively impacts their health status. The causes will also impact condemnation decisions regarding carcasses of animals from emergency slaughters because they reflect the severity of the stress experienced by different categories of the cattle. Based on the identification of the causes of stress from a large number of observations over a sufficiently long period of time measures may be taken in herds designed to improve the health of animals and reduce the severity of the stresses, which may then be positively reflected in condemnation decisions for emergency slaughter carcasses.

It follows from the results obtained that the most frequent cause of emergency slaughters in the category of calves were diseases of the respiratory apparatus, and that the incidence level was very high. This finding is in agreement with the results published for calves slaughtered at abattoirs by Ju lini (1993). In their monitoring study, B is s et al. (1994) also reported a large ratio of pneumonias (besides the diseases of the navel) among calves compared with other diseases found. The number of emergency slaughters for respiratory apparatus diseases are on a moderately upward during period II. The carcass condemnation ratio is very high, with an increase during period II. This finding is in agreement with observations of Kozák et al. (2002), who reported a growing trend in the number of condemned carcasses of calves slaughtered at abattoirs.

In heifers, the majority of causes for emergency slaughter are locomotor apparatus diseases, and in aggregate, the emergency slaughter causes are responsible for the fact that about a third of heifer carcasses from emergency slaughters are condemned.

In the cows category, the most frequent cause for the emergency slaughter were diseases of the locomotor apparatus at a very high incidence level, and diseases of other aetiologies, which also includes diseases of the kidneys and the liver. These findings are in agreement with results published by Julini (1993), who reported very frequent renal lesions in cows, and with results published by Giaccone et al. (1994), who reported frequent liver lesions in the cattle. The ratio of condemned cow carcasses is high, with a moderately upward trend during period II, which is in agreement with results published by Kozák et al. (2002), who also reported a long term growing trend in the number of condemned carcasses of cows slaughtered at abattoirs.

In slaughter bulls, the locomotor apparatus diseases are the reason for emergency slaughter in well over half of the cases. The aggregate impact of emergency slaughter causes on the number of condemned slaughter bull carcasses is less marked than that in other cattle categories.

Measures that need to be taken to improve health of cattle herds should focus on respiratory apparatus diseases in the calves, and locomotor apparatus diseases in other cattle categories.

\section{Nutné porážky u skotu: nejčastější příčiny a jejich výskyt v České republice v období let 1997-2002}

Cílem práce bylo zjistit nejčastější př́ǐiny nutných porážek u skotu a porovnat jejich výskyt ve dvou navazujících obdobích. V období let 1997 až 2002 byly sledovány nutné porážky u telat, jalovic, krav a jatečných býků na jatkách v celé České republice. Př́íciny nutných porážek byly členěny do skupin: nákazy, onemocnění dýchacího aparátu, onemocnění zažívacího aparátu, onemocnění pohybového aparátu, poporodní komplikace, onemocnění jiné etiologie. Bylo porovnáno období let 2000 až 2002 (II. období) s obdobím 
let 1997 až 1999 (I. období) na základě indexu poměru relativní četnosti nálezů II. období k I. období. U telat byl zjištěn nejčastější výskyt onemocnění dýchacího aparátu $(47,43 \%)$ s mírným vzestupem v II. období (index 1,07$)$, který byl statisticky vysoce významný $(P \leq$ $0,01)$. U jalovic, krav a býků byl zjištěn nejčastější výskyt onemocnění pohybového aparátu mírným vzestupem v II. období (jalovice 43,07\% a index 1,07, krávy 35,30\% a index 1,07, býci 58,27\% a index 1,06), které byly statisticky vysoce významné (jalovice $P \leq 0,01$; krávy $P \leq 0,01$, býci $P \leq 0,01)$. Nutné porážky u jednotlivých kategorií skotu se různě promítaly do četnosti rozhodnutí o nepoživatelnosti (telata $61,24 \%$, jalovice $30,14 \%$, krávy 45,16\%, býci 17,92\%) s vzestupem u telat (index 1,23) a u krav (index 1,08) v II. období, které byly vysoce významné (telata $P \leq 0,01$; krávy $P \leq 0,01$ ) a s neprokázaným rozdílem mezi I. obdobím a II. obdobím u jalovic (index 1,00) a u býků (index 1,00), statisticky pro jalovice $P=0,89$; pro býky $P=0,93$. Z hlediska změn potřebných v chovech skotu k zlepšování jejich zdravotního stavu a snižování nutných porážek je třeba provádět opatření zaměřená na onemocnění dýchacího aparátu u telat a onemocnění pohybového aparátu u ostatních kategorií skotu.

\section{Acknowledgments}

This paper was prepared as a part of Research Project of the Ministry of Education, Youth and Sports of the Czech Republic No. 16270005 "Research of current hygienic aspects of production of food and raw materials of animal origin with regard to their safety."

\section{References}

GIACCONE, V, JULINI, M, GILI, S, RATTAZII, C, CACCIATORE, A 1994: Incidence of hepatic lesions at meat inspections. Ind Aliment - Italy 33: 1245-1247

KOFER, J, KUTSCHERA, G, FUCHS, K 2001: Monitoring of animal health at abattoirs. Fleischwirtschaft 81: 107-111

BISS, M, E, ALLE, M, R, MADIE, P, HATHAWAY, S,C, 1994: Lesions in the carcasses and viscera of very young slaughter calves condemned at post-mortem meat inspection. N Z Veter J. 42: 121-127

JULINI, M 1993: The slaughterhouse as an epidemiologic observatory. Ind Aliment - Italy 32: 1075-1078

KOZÁK, A, VEČEREK, V, STEINHAUSEROVÁ, I, CHLOUPEK, P, PIŠTĚKOVÁ, V 2002: Results of slaughterhouse carcass classification (capable for human consumption, capable for processing and condemned) in selected species of food animals. Vet Med - Czech 47: 26-31

WYSS, R 1996: Carcass hygiene - inspection of beef carcasses. Fleischwirtschaft 76: 46-47 